\section{MG Travessia: a coffee arabica cultivar productive and responsive to pruning}

\author{
Gladyston Rodrigues Carvalho ${ }^{1^{*}}$, Gabriel Ferreira Bartholo², \\ Antônio Alves Pereira ${ }^{3}$, Juliana Costa de Rezende ${ }^{1}$, Cesar Elias \\ Botelho ${ }^{1}$, Antônio Carlos Baião de Oliveira ${ }^{2}$ and Felipe Lopes \\ da Silva ${ }^{4}$
}

\begin{abstract}
This paper presents the results of progeny 1190-1170-2, which was recorded as 'MGS Travessia' and selected based on its performance in the state of Minas Gerais. The cultivar has short size, cylindrical canopy, high yield capacity, high vegetative vigor, very satisfactory husk/bean ratio, grain quality compatible to traditional cultivars, and is very responsive to skeleton pruning.
\end{abstract}

Key words: Coffea arabica, selection, plant breeding.

\section{INTRODUCTION}

In order to recover important alleles from 'Mundo Novo' cultivar; to diversify the traits of 'Catuaí' cultivar; and to select earlier and more vigorous, productive, uniform fruit maturation forms, artificial crosses were carried out by the Agronomic Institute of Campinas (Instituto Agronômico de Campinas - IAC), in the 60s, between 'Catuaí' and 'Mundo Novo' cultivar (Carvalho et al. 2008). In the early 70s, with the introduction of these genetic materials in the state of Minas Gerais, by the State System of Agricultural Research System (Empresa de Pesquisa Agropecuária de Minas Gerais- EPAMIG/ Universidade Federal de Lavras- UFLA/ Universidade Federal de Viçosa- UFV), new backcrosses were carried out, and selections were intensified, resulting in 'Rubi' and 'Topázio' cultivars.

Subsequently, evaluations and selection of segregating progenies were carried out; these progenies resulted from a cross between 'Catuaí Amarelo IAC H 2077-2-12-70' and 'Mundo Novo IAC 515-20', which presented potential to generate progenies with traits of interest. Thus, this study aimed to obtain an Arabica coffee cultivar carrying traits demanded by coffee farmers and coffee drinkers, which were selected based on the performance, especially yield, after nine harvests, being the last one after skeleton pruning.

\section{MATERIAL AND METHODS}

Experiments were carried out in EPAMIG's Experimental Farms located in the municipalities of Três Pontas and São Sebastião do Paraíso, and on private farms in the municipalities of Capelinha (Fazenda Resplendor) and Campos Altos (Fazenda Ouro Verde). Thus, the main coffee regions of the state were represented in the experiment (South and Southwest of Minas Gerais, Vale do Jequitinhonha and Alto Paranaíba). Table 1 shows the edaphoclimatic
Crop Breeding and Applied Biotechnology 17: 287-291, 2017 Brazilian Society of Plant Breeding. Printed in Brazil http://dx.doi.org/10.1590/1984$70332017 v 17 n 3 c 43$

\footnotetext{
*Corresponding author: E-mail: carvalho@epamig.br
}

Received: 04 November 2016 Accepted: 19 March 2017

${ }^{1}$ Empresa de Pesquisa Agropecuária de Minas Gerais (EPAMIG), Unidade Sul, Campus da Universidade Federal de Lavras (UFLA), CP 176, 37.200-000, Lavras, MG, Brazil ${ }^{2}$ Embrapa Café, Parque Estação Biológica PqEB., 70.770-901, Brasília, DF, Brazil ${ }^{3}$ EPAMIG, Unidade Sudeste, Vila Gianetti, 46/47, Campus da UFV, 36.570-000, Viçosa, MG, Brazil

${ }^{4}$ Universidade Federal de Viçosa (UFV), Departamento de Fitotecnia, Avenida P.H. Rolfs, 36.570-000, Viçosa, MG, Brazil 
characteristics of the experiments sites.

The performance of the commercial cultivars 'Catuaí Vermelho IAC 99', Rubi MG 1192', 'Acaiá Cerrado 1474', 'Catuaí Vermelho IAC 144' and 'Catuaí Amarelo IAC 62' was assessed together with other progenies developed by EPAMIG's coffee breeding program. This progenies are in the fourth generation by self-fertilization after the second backcross between 'Catuaí Amarelo IAC H 2077-2-12-70' and 'Mundo Novo IAC 515-20'. This paper presents the results of '11901170-2' progeny, which was registered at the National Register of Cultivars of the Ministry of Agriculture, Livestock and Supply (RNC/MAPA), as 'MGS Travessia'. This cultivar was selected among other tested progenies since it excelled in all the analyzed traits.

Experiments were carried out in a randomized block design with four replications and six plants per plot, all of which were considered useful, spaced $2.50 \times 0.70 \mathrm{~m}$ apart (Três Pontas), $3.50 \times 1.00 \mathrm{~m}$ (São Sebastião do Paraíso), and 3.50 x $0.50 \mathrm{~m}$ (Campos Altos and Capelinha). Experiments were carried out according to the technical recommendations for Arabica coffee culture for the state of Minas Gerais (Reis and Cunha 2010). Preventive or curative phytosanitary treatment was performed by chemicals, according to seasonality of pests and diseases.

The yield was analyzed annually in liters of freshly harvested coffee per plot. Coffee plants were harvested between the months of May and August each year. Subsequently, the yield was converted into yield of $60 \mathrm{~kg}$ bags of green coffee per hectare (bags ha-1). This conversion was carried out by approximating the values, considering mean yield of 480 liters of freshly harvested coffee for each bag of $60 \mathrm{~kg}$ processed coffee (Carvalho et al. 2009). During analyses, mean yield $\left(\right.$ bags ha ${ }^{-1}$ ) per biennium was considered, which was obtained by the mean of two consecutive harvests. The experiments in Três Pontas and São Sebastião do Paraíso were assessed in eight harvests and those in Campos Altos and Capelinha were assessed in six harvests.

After the eighth harvest, skeleton pruning was carried out in the coffee from Três Pontas. There, some traits, such as yield, vegetative vigor, percentage of floating grains and high sieve grains were assessed before and after pruning. Husk/bean ratio and percentage of peaberry grains after pruning were also assessed. Percentage of floating grains fruits was measured by the method proposed by Antunes and Carvalho (1957), by placing 100 cherry coffee fruits in water, and those which remained on the surface were considered floating. Husk/bean ratio was obtained by gallons of coffee harvested in the Field divided by the number of processed coffee bags per hectare. Samples of $500 \mathrm{~g}$ of coffee from each plot were used to classify the grains by size, in interleaved screens of different sizes. High sieve grains classification was carried out by the sum of screen 16 and above, and the peaberry grains were classified by the sum of grains retained in screen 10 and below. The screens used in the experiment were specific for the classification of these grains (Brazil 2003). Statistical analyses were carried out using the software Sisvar (Ferreira 2008). The means of the assessed traits were grouped by the Scott-Knott test, at a $5 \%$ probability $(p<0.05)$.

\section{RESULTS AND DISCUSSION}

Significant effect $(p<0.05)$ was found for yield for all cultivars in the four study sites. Cultivar 'MGS Travessia' stood out regarding grain yield in São Sebastião do Paraíso. It formed an isolated group in the mean comparison by the Scott-Knott test (Table 2). In the experiment installed in Campos Altos, two medium-sized groups were observed, and the top position was occupied by 'MGS Travessia', 'Rubi MG 1192', 'Acaiá Cerrado 1474' and 'Catuaí Amarelo IAC 62', with yields between 60.06 and 67.91 bags ha-1. Similarly, in Capelinha, 'MGS Travessia', 'Rubi MG 1192', 'Acaiá Cerrado 1474', 'Catuaí Vermelho IAC 144' and 'Catuaí Amarelo IAC 62' stood out with the highest yield. Mean yield evaluation in Três Pontas formed three groups: 'Rubi MG 1192' occupied the top position, bottom position was occupied by 'Catuaí Vermelho IAC 99' and 'Acaiá Cerrado 1474', leaving 'MGS Travessia' in an intermediate position, with a mean yield of 41.32 bags ha-1 $^{-1}$ (Table 2 ).

One of the objectives of the cross that originated 'MGS Travessia' cultivar was to give 'Catuai' cultivar greater vegetative vigor (Fazuoli et al. 2002). By the results observed in the assessments for this trait, this objective was achieved, since 'MGS Travessia' cultivar had a high mean for vegetative vigor (Table 3). These results are similar to those obtained in the evaluation of 'Rubi MG 1192', which is considered a very strong genetic material (Carvalho et al. 2008) and can be attributed to the high vegetative vigor presented by 'Mundo Novo IAC 515-20', one of the parents used in the artificial cross that originated 'MGS Travessia'. 
MG Travessia: a coffee arabica cultivar productive and responsive to pruning

Table 1. Edaphoclimatic characteristics of the experimental sites

\begin{tabular}{|c|c|c|c|c|}
\hline Traits & Três Pontas & São Sebastião do Paraíso & Campos Altos & Capelinha \\
\hline Local relief & wavy & slightly wavy & flat & wavy \\
\hline Altitude & $900 \mathrm{~m}$ & $890 \mathrm{~m}$ & $1.230 \mathrm{~m}$ & $820 m$ \\
\hline Latitude & $21^{\circ} 22^{\prime} 01^{\prime \prime} \mathrm{S}$ & $20^{\circ} 55^{\prime} \mathrm{S}$ & $19^{\circ} 41^{\prime} 47^{\prime \prime} \mathrm{S}$ & $21^{\circ} 40^{\prime} \mathrm{S}$ \\
\hline Longitude & $45^{\circ} 30^{\prime} 45^{\prime \prime} \mathrm{W}$ & $46^{\circ} 55^{\prime} W$ & $46^{\circ} 10^{\prime} 17^{\prime \prime} \mathrm{W}$ & $45^{\circ} 55^{\prime} \mathrm{W}$ \\
\hline Annual Precipitation* & $1670 \mathrm{~mm}$ & $1470 \mathrm{~mm}$ & $1830 \mathrm{~mm}$ & $1450 \mathrm{~mm}$ \\
\hline Annual Temperature* & $20.1^{\circ} \mathrm{C}$ & $20.8^{\circ} \mathrm{C}$ & $17.6^{\circ} \mathrm{C}$ & $21.3^{\circ} \mathrm{C}$ \\
\hline
\end{tabular}

* Annual average data.

Table 2. Mean yield of processed coffee in bags ha-1 of the studied cultivars in the first eight harvests in Três Pontas and São Sebastião do Paraíso and in the first six harvests in Capelinha and Campos Altos

\begin{tabular}{|c|c|c|c|c|}
\hline Cultivars & São Sebastião do Paraíso & Campos Altos & Capelinha & Três Pontas \\
\hline MGS Travessia & $22.86 a$ & $60.06 a$ & $35.86 a$ & $41.32 \mathrm{~b}$ \\
\hline Catuaí vermelho IAC 99 & $18.70 \mathrm{~b}$ & $53.63 b$ & $19.41 b$ & $34.35 \mathrm{c}$ \\
\hline Rubi MG 1192 & $20.90 b$ & $61.67 a$ & $25.29 a$ & $47.00 \mathrm{a}$ \\
\hline Acaiá Cerrado 1474 & $15.90 \mathrm{~b}$ & $60.88 a$ & $31.86 a$ & $31.83 \mathrm{c}$ \\
\hline Catuaí vermelho IAC 144 & $20.86 b$ & $53.61 b$ & $35.23 a$ & - \\
\hline Catuaí amarelo IAC 62 & - & $67.91 a$ & $25.74 a$ & - \\
\hline
\end{tabular}

Means followed by the same letter do not differ by the Scott-Knott test $(P<0.05)$.

Table 3. Mean coffee vegetative vigor; mean percentage of floating grains and mean percentage of high sieve grains assessed in the eighth harvest (before pruning) of four Arabica coffee cultivars in experiment installed in the EPAMIG's Experimental Farm in Três Pontas

\begin{tabular}{llcc}
\hline Cultivars & Vigor & Floating grains & Sieve \\
MGS Travessia & $7.33 \mathrm{a}$ & $5.00 \mathrm{a}$ & $49.00 \mathrm{~b}$ \\
Catuaí vermelho IAC 99 & $5.33 \mathrm{~b}$ & $4.67 \mathrm{a}$ & $49.00 \mathrm{~b}$ \\
Rubi MG 1192 & $7.33 \mathrm{a}$ & $3.00 \mathrm{a}$ & $45.00 \mathrm{c}$ \\
Acaiá Cerrado 1474 & $6.33 \mathrm{~b}$ & $4.33 \mathrm{a}$ & $66.67 \mathrm{a}$ \\
\hline
\end{tabular}

Means followed by the same letter do not differ by the Scott-Knott test $(P<0.05)$.

There were no significant differences between the percentages of floating grains for the cultivars (Table 3). According to Carvalho et al. (2006), less than $10 \%$ of floating grains is considered satisfactory by breeders during evaluation and selection of coffee in breeding programs, since most of the commercial lines present percentage around that level. In this study, all cultivars had floating grains percentages ranging from $3-5 \%$ (Table 3 ). This trait again shows the potential of these genetic materials, since the smaller the percentage of floating grains, the greater is the yield of cherry coffee when compared with processed coffee, and consequently the greater is the yield potential of the cultivar.

The classification of grain in high sieve grains detected the formation of three distinct groups by the Scott-Knott test $(p<0.05)$. 'Acaiá Cerrado 1474' stood out, since it presents well-developed grains. 'Rubi MG 1192' cultivar was the one with the lowest percentage of grains retained in high screens, while 'MGS Travessia' and 'Catuaí Vermelho IAC 99' cultivars are in intermediate position (Table 3).

\section{Cultivar behavior after pruning}

The traits yield, husk/bean ratio, percentage of floating grains, high sieve grains, and peaberry grains were assessed after skeleton pruning, in Três Pontas (Table 4). Regarding yield, 'MGS Travessia' presented best post-pruning performance. Although data refer to the first harvest after pruning, it can be inferred that 'MGS Travessia' had excellent response to skeleton pruning, which rises great interest, especially for farmers who opt by production system "Safra Zero".

'Acaiá Cerrado MG 1474' stood out for requiring only 380.12 liters of freshly harvested coffee for each $60 \mathrm{~kg}$ bag of processed coffee. On the other hand, the other cultivars showed lower husk/bean ratio, requiring larger volumes of freshly harvested coffee to fill a $60 \mathrm{~kg}$ bag of processed coffee (Table 4). Higher percentage of well-developed grains was observed, when compared with floating ones, for all cultivars, ranging from $94.70 \%$ to $97.57 \%$. 'Rubi MG 1192 ' and 
Table 4. Mean yield (bags ha-1); husk/bean ratio (gallons of coffee harvested in the field divided by the number of processed coffee bags per hectare); percentage of floating grains, of grains classified in high sieve grains, and peaberry grains, assessed after pruning. EPAMIG's Experimental Farm, Três Pontas

\begin{tabular}{lccccc}
\hline Cultivars & Yield & Husk/bean ratio & Floating grains & High sieve & Peaberry grains \\
MGS Travessia & $99.40 \mathrm{a}$ & $456.19 \mathrm{~b}$ & $5.30 \mathrm{~b}$ & $72.21 \mathrm{~b}$ & $7.90 \mathrm{a}$ \\
Catuaí Vermelho IAC 99 & $72.90 \mathrm{~b}$ & $455.81 \mathrm{~b}$ & $4.96 \mathrm{~b}$ & $78.61 \mathrm{a}$ & $7.66 \mathrm{a}$ \\
Rubi MG 1192 & $81.43 \mathrm{~b}$ & $487.98 \mathrm{~b}$ & $3.24 \mathrm{a}$ & $81.31 \mathrm{a}$ & $6.33 \mathrm{a}$ \\
Acaiá Cerrado 1474 & $79.17 \mathrm{~b}$ & $380.12 \mathrm{a}$ & $2.43 \mathrm{a}$ & $84.30 \mathrm{a}$ & $7.24 \mathrm{a}$ \\
\hline
\end{tabular}

Means followed by the same letter do not differ by the Scott-Knott test $(P<0.05)$.

'Acaiá Cerrado MG 1474' stood out for presenting smaller percentages of floating grains (Table 4).

Two groups with different means were formed by high sieve grains. 'Catuaí Vermelho IAC 99', 'Rubi MG 1192' and 'Acaiá Cerrado MG 1474' (Table 4) were found at the highest position; and 'MGS Travessia' was found at the bottom position, with $72.21 \%$ of grains classified in high sieve grains. Thus, all the assessed genetic materials showed high percentage of grains classified in high sieve grains. These results are very relevant, since this is a trait of great interest in coffee business, due to its high commercial value.

No significant difference was found among cultivars in percentage of peaberry grains, since they all presented low percentage for this type of grain (Table 4). There is no requirement for maximum content of peaberry grains as a criterion for assessing the quality of an Arabica coffee plant variety. Guimarães et al. (2002) reported that for seeds, standardization criteria indicate tolerance of up to $12 \%$ peaberry grains. Therefore, results observed in this study indicate that all cultivars showed very satisfactory values for this trait.

\section{Other morpho-agronomic descriptors}

Other morpho-agronomic descriptors were observed in 'MGS Travessia' (Table 5). The cultivar has low to medium size, similar to 'Catuaí Vermelho IAC 99', and cylindrical canopy architecture. The canopy radius is medium. The plagiotropic branches have short internodes, with abundant side branches. It has yellow fruits when ripe, oblong and green colored leaves with curled edge. Grains have intermediate size and short and wide shape.

\section{Planting recommendations}

'MGS Travessia' presented excellent agronomic behavior in three major regions of the state of Minas Gerais, showing wide adaptation in very diverse environments. Therefore, this cultivar of intermediate maturation cycle may be planted safely in several producing regions of Minas Gerais. Spacing suitable for planting is at least $2.50 \times 0.70 \mathrm{~m}$. Conditions for growing and cultivation are similar to those recommended for Topázio MG 1190 cultivar. 'MGS Travessia' has also been recommended for the production system "Safra Zero", due to its high responsiveness to skeleton pruning.

\section{ACKNOWLEDGMENTS}

To the National Science and Technology Institute (INCT-Café/CNPq), to the Coffee Research Consortium, and the Research Support Foundation of the State of Minas Gerais (Fapemig) for financial support for the project, and to the owners of Ouro Verde and Resplendor Farms for making the experimental area available. To the fellowship of research productivity (PQ) granted by the National Council for Scientific and Technological Development (CNPq) and Fapemig. 
MG Travessia: a coffee arabica cultivar productive and responsive to pruning

\section{REFERENCES}

Antunes Filho H and Carvalho A (1957) Melhoramento do cafeeiro, ocorrência de lojas vazias em frutos de café Mundo Novo. Bragantia 13: $165-179$.

Brasil - Ministério da Agricultura, Pecuária e Abastecimento (2003) Instrução Normativa n. 8, 11 de junho de 2003. Available at <http:www.abic.com.br/arquivos/abic_nm_a1d_inst_normativa 08.pdf>. Accessed on Jan 3, 2009.

Carvalho CHS, Fazuoli LC, Carvalho GR, Guerreiro Filho O, Pereira AA, Almeida SR, Matiello JB, Bartholo GF, Sera T, Moura WM, Mendes ANG, Rezende JC, Fonseca AFA, Ferrão MAG, Ferrão RG, Nacif AP, Silvarolla MB and Braghini MT (2008) Cultivares de café arábica de porte baixo. In Carvalho CHS (ed) Cultivares de café: origem, características e recomendações. Embrapa Café, Brasília, p. 155-252.

Carvalho GR, Botelho CE, Bartholo GF, Pereira AA, Nogueira AM and Carvalho AM (2009) Comportamento de progênies $F_{4}$ obtidas por cruzamentos de 'Icatu' com 'Catimor'. Ciência e Agrotecnologia 33: 47-52.

Carvalho GR, Mendes ANG, Bartholo GF and Amaral MA (2006) Avaliação e seleção de progênies resultantes do cruzamento de cultivares de café Catuaí com Mundo Novo. Ciência e Agrotecnologia 30: 844-852.

Fazuoli LC, Filho HPM, Gonçalves W, Gerreiro Filho O and Silvarolla MB (2002) Melhoramento do Cafeeiro: variedades do tipo arábica obtidas no Instituto Agronômico de Campinas. In Zambolim L (org) 0 estado da arte de tecnologias na produção de café. UFV, Viçosa, p. 163-216.

Ferreira DF (2008) Sisvar: um programa para análises e ensino de estatística. Revista Symposium 6: 36-41.

Guimarães RJ, Mendes ANG and Souza CAS (2002) Colheita. In Guimarães RJ, Mendes ANG and Souza CAS (eds) Cafeicultura. UFLA/FAEPE, Lavras, p. 285-300.

Reis PR and Cunha RL (2010) Café arábica do plantio a colheita. Embrapa Informação Tecnológica, Brasília, 896p. 